\title{
Efek antikaries ekstrak gambir pada tikus jantan galur wistar
}

\author{
Siti Rusdiana Puspa Dewi*, Dina Oktavia Marlamsya**, Rini Bikarindrasari* \\ *Bagian Konservasi Gigi, Program Studi Kedokteran Gigi, Fakultas Kedokteran, Universitas Sriwijaya, Palembang, Sumatera Selatan, Indonesia \\ **Program Studi Kedokteran Gigi, Fakultas Kedokteran, Universitas Sriwijaya, Palembang, Sumatera Selatan, Indonesia \\ *JI Palembang-Prabumulih Km 32, Indralaya, Palembang, Sumatera Selatan, Indonesia; e-mail: sitrus.pd@gmail.com
}

Submisi: 27 Desember 2016; Penerimaan: 3 Januari 2017; Publikasi online: 31 Agustus 2017

\begin{abstract}
ABSTRAK
Beberapa penelitian terdahulu mengatakan bahwa ekstrak gambir dapat menghambat pertumbuhan Steptococcus mutans (S. mutans) karena mengandung zat aktif katekin dan tanin. Tujuan dari penelitian ini adalah untuk melihat efek antikaries ekstrak gambir pada tikus jantan galur Wistar. Tiga puluh enam ekor tikus galur Wistar diinokulasi dengan S. mutans, diberikan makanan kariogenik dan dibagi menjadi 4 kelompok, yakni, kelompok yang diberi dosis ekstrak gambir $6 \mathrm{mg}, 12 \mathrm{mg}, 24 \mathrm{mg}$ dan plasebo. Setelah 60 hari, tikus di eutanasia, kemudian dihitung jumlah karies pada permukaan halus dan oklusal dengan menggunakan metode Keyes. Data dianalisa dengan menggunakan tes Kruskal Wallis. Hasil penelitian diketahui bahwa karies ditemukan hanya pada pemukaan oklusal dengan kedalaman email. Tidak ada perbedaan signifikan antar semua kelompok, sehingga dapat disimpulkan bahwa ekstrak gambir dengan dosis $6 \mathrm{mg}$, $12 \mathrm{mg}$ dan $24 \mathrm{mg}$ tidak memiliki efek antikaries pada gigi tikus jantan galur Wistar.
\end{abstract}

Kata kunci: antikaries; ekstrak gambir; karies

\begin{abstract}
Anti-caries effect of gambier extract on male wistar rats. Several previous studies have mentioned that gambir extract can inhibit the growth of Streptococcus mutans (S. mutans) because it contains active substances of catechins and tannins. The objective of this study was to explore the anti-caries effect of gambir extract on male Wistar rats. Thirty-six Wistar rats were inoculated with S. mutans, given cariogenic foods and divided into 4 groups according to the doses of gambir extract, namely $6 \mathrm{mg}, 12 \mathrm{mg}, 24 \mathrm{mg}$ and placebo. After 60 days, the rats were euthanized, then the number of caries on the mesial or distal and occlusal surfaces was counted by using the Keyes' method. The data were analyzed using Kruskal Wallis test. The results revealed that caries was found only in occlusal surfaces with an enamel depth. There is no significant difference among all the groups, so it can be concluded that gambir extract at $6 \mathrm{mg}, 12 \mathrm{mg}$ and $24 \mathrm{mg}$ doses do not have anti-caries effect on the teeth of male Wistar rats.
\end{abstract}

Keywords: anti-caries; gambir extract; caries

\section{PENDAHULUAN}

Penyakit gigi dan mulut merupakan masalah kesehatan tertinggi keenam yang sering dikeluhkan oleh masyarakat Indonesia. ${ }^{1}$ Salah satu penyakit gigi dan mulut yang mempunyai prevalensi cukup tinggi di Indonesia ialah karies gigi. Data Riskesdas 2013 menyebutkan bahwa prevalensi penduduk Indonesia yang bermasalah dengan gigi dan mulut mencapai lebih dari $35 \%{ }^{2}$

Karies gigiadalah suatu penyakitjaringan keras gigi yang diakibatkan oleh aktivitas mikroorganisme dalam memfermentasikan karbohidrat sehingga terbentuk asam dan menurunkan $\mathrm{pH}$, dengan ditandai adanya demineralisasi jaringan keras gigi. ${ }^{3}$ Salah satu faktor yang berperan dalam proses terjadinya karies ialah mikroorganisme yang terdapat di dalam plak gigi. Streptococcus mutans
(S. mutans) merupakan bakteri kariogenik yang memiliki peranan penting dalam pembentukan plak. Streptococcus mutans dapat menghasilkan enzim glukosiltransferase dan fruktosiltransferase. Enzim tersebut mengubah sukrosa menjadi polisakarida ekstraselular berbentuk glukan dan fruktan. Glukan bersifat lengket sehingga mendukung perlekatan bakteri-bakteri asidogenik lainnya pada kolonisasi awal pembentukan plak. ${ }^{4}$

Salah satu upaya pencegahan terhadap karies gigi ialah dilakukan pengembangan bahan alam dengan memanfaatkan gambir (Uncaria gambir [Roxb.]) yang diketahui sebagai salah satu bahan antibakteri. Ekstrak gambir mengandung katekin sebagai komponen utama serta beberapa komponen lain seperti asam kateku tanat, kuersetin, kateku merah, gambir flouresen, lemak dan lilin. ${ }^{5}$ 
Kemampuan antibakteri gambir tergantung dari kandungan katekin dalam gambir. Katekin mampu menghambat pembentukan polisakarida ekstraseluler, glukan, melalui persaingan kompetitif dengan enzim glukosiltransferase. Kandungan katekin pada gambir memiliki aktivitas antibakteri yang dapat menghambat pertumbuhan bakteri Gram positif. ${ }^{6,7}$ Pambayun dkk (2008) menyatakan bahwa konsentrasi ekstrak gambir 6\% mampu membunuh $100 \%$ bakteri S. mutans. ${ }^{8}$ Amos (2009) melaporkan bahwa aktivitas antibakteri pada obat kumur yang mengandung gambir berada pada konsentrasi $24 \% .{ }^{9}$ Lucida dkk (2010) menyebutkan bahwa ekstrak gambir $7 \%$ yang terdapat dalam pasta gigi memiliki daya antimikroba yang optimal dalam menghambat pertumbuhan bakteri $S$. mutans sebagai penyebab terbentuknya plak gigi. ${ }^{10}$

Sampai dengan saat ini, penelitian ekstrak gambir sebagai antikaries secara in vivo masih sangat terbatas, oleh karena itu, penelitian ini bertujuan mengetahui efek antikaries ekstrak gambir pada gigi tikus jantan galur Wistar yang induksi dengan bakteri $S$. mutans. Pemilihan hewan percobaan tikus galur Wistar selain karena pada alasan ekonomis dan praktis melainkan juga mudah dikembangbiakan. ${ }^{11}$

\section{METODE PENELITIAN}

Penelitian ini telah dilakukan uji kelayakan etik oleh Komisi Etik Penelitian Rumah Sakit Umum Pusat Mohammad Hoesin Palembang dan Fakultas Kedokteran Universitas Sriwijaya dengan sertifikat etik No.112/kepkrsmhfkunsri/2016. Jenis penelitian yang digunakan adalah penelitian eksperimental laboratoris secara in vivo dengan rancangan penelitian posttest-only control group design. Penelitian dilakukan di Laboratorium Biomolekuler dan Animal House Fakultas Kedokteran Universitas Sriwijaya, Palembang. Penelitian dilakukan pada bulan Agustus - November 2016.

Alat-alat yang digunakan dalam penelitian ini adalah botol minuman, tempat makanan tikus, sarung tangan karet (handscoen), kertas saring, kapas, alat soxhlet, rotary evaporator, gelas ukur, alumunium foil, mortar dan pestle, neraca analitik, timbangan digital, scalpel dan blade \#10, pinset, tabung kecil, USB Digital Microscope pada pembesaran 300-350x, mikromotor dan straight handpiece, carborondum disk dengan ketebalan $0,3 \mathrm{~mm}$ dan diameter $2 \mathrm{~cm}$. Bahan penelitian yang digunakan adalah daun gambir (Uncaria gambir [Roxb.]) yang diambil dari Babat Toman, Sumatera Selatan, air dan makanan tikus yang diberi sukrosa. Sampel penelitian menggunakan tikus putih galur Wistar (Rattus norvegicus L.). Kriteria inklusi tikus yang digunakan adalah tikus putih galur Wistar (Rattus norvegicus L.) berjenis kelamin jantan, berusia $10-12$ minggu, berat $150-250$ gram, dan dalam keadaan sehat. Kriteria eksklusi pada penelitian ini adalah tikus dalam keadaan cacat fisik dan mental. Jumlah sampel adalah 32 ekor tikus, yang dibagi dalam 4 kelompok, yakni kelompok 1 yang diberi plasebo (akuades), kelompok 2 dengan dosis $6 \mathrm{mg} / 200 \mathrm{gr} \mathrm{BB}$, kelompok 3 dengan dosis $12 \mathrm{mg} / 200 \mathrm{gr}$ BB dan kelompok 4 dengan dosis 24 $\mathrm{mg} / 200 \mathrm{gr} \mathrm{BB}$ tikus.

\section{Pembuatan Ekstrak Gambir}

Daun gambir dijemur hingga kering selama 48 jam tanpa mengenai sinar matahari langsung. Proses pengeringan juga dibantu dengan oven selama \pm 1,5 jam. Daun yang kering tersebut dihancurkan dan diblender sampai halus hingga menjadi simplisia. Sebanyak $60 \mathrm{gr}$ simplisia dibungkus dengan kertas saring dan kapas sebagai alasnya, kemudian dimasukkan ke dalam tabung soxhlet. Tabung soxhlet diisi dengan pelarut etanol $96 \%$, $700 \mathrm{ml}$ dan dilakukan pemanasan pada suhu titik didih pelarut yaitu $78,3{ }^{\circ} \mathrm{C}$. Ekstraksi dilakukan selama $10 \mathrm{jam}$. Ekstrak yang diperoleh dievaporasi menggunakan alat rotary evaporator pada suhu 50 ${ }^{\circ} \mathrm{C}$. Hasil ekstraksi tersebut diletakkan di wadah kaca dan diangin-anginkan hingga mendapat ekstrak kering. Ekstrak gambir disimpan di dalam kulkas, kemudian digerus dengan menggunakan mortar dan pestle. Ekstrak ditimbang dengan neraca analitik dan dibagi dalam beberapa dosis, kemudian dibungkus dalam alumunium foil yang diberi label sesuai dengan dosis masing-masing.

Ekstrak gambir dibuat dengan metode sokletasi dan dibagi dalam 3 dosis, yaitu dosis $6 \mathrm{mg} / 200 \mathrm{~g}$ BB tikus, $12 \mathrm{mg} / 200 \mathrm{~g}$ BB tikus, dan $24 \mathrm{mg} / 200 \mathrm{~g}$ BB tikus. Dosis ini dipilih berdasarkan 
penelitian yang dilakukan oleh Hasti dkk (2012) $)^{12}$, yang menunjukkan bahwa ekstrak gambir dengan dosis terendah $6 \mathrm{mg} / 200 \mathrm{~g} \mathrm{BB}$ mempunyai aktivitas hepatoproteksi pada tikus. Kemudian, dosis gambir $6 \mathrm{mg}$ ditingkatkan menjadi $12 \mathrm{mg}$ dan $24 \mathrm{mg}$.

Makanantikusyang digunakandalampenelitian dicampur dengan sukrosa sebagai bahan makanan kariogeniknya. ${ }^{13}$ Cara pengolahannya ialah $600 \mathrm{mg}$ sukrosa dilarutkan dengan menggunakan aquades $1000 \mathrm{ml}$. Kemudian makanan dasar dicampurkan ke dalam larutan sukrosa ( $1 \mathrm{~kg}$ pelet: $500 \mathrm{ml}$ sukrosa) dan diaduk sampai merata. Kelembaban makanan dihilangkan dengan menggunakan microwave.

\section{Persiapan Hewan Percobaan}

Persiapan hewan percobaan dimulai dengan aklimatisasi. Aklimatisasi merupakan proses penyesuaian hewan percobaan terhadap perubahan iklim lingkungan. Pada penelitian ini, aklimatimasi perlu dilakukan karena tikus Wistar yang dijadikan hewan percobaan diambil dari kota Bandung dengan surat keterangan kesehatan hewan dari Dinas Pertanian dan Ketahanan Pangan no. 524.3/1755-Dispertapa/2016, sedangkan penelitian dilakukan di kota Palembang. Adanya perbedaan wilayah dan iklim dikhawatirkan akan menyebabkan perbedaan fisiologis dan perilaku suatu organisme, dalam hal ini tikus Wistar. Oleh karena itu, aklimatimasi dibutuhkan untuk mengobservasi perilaku dan kemampuan adaptasi tikus terhadap lingkungan barunya. Tikus yang tidak memiliki adaptasi baik dengan lingkungannya, memiliki perilaku yang berbeda dengan yang lainnya akan dikeluarkan dari sampel penelitian.

Tikus diaklimatisasi dalam ruangan penelitian selama \pm 1 minggu pada suhu kamar. Pada saat aklimatisasi, tikus diberi makanan berupa pelet sebanyak $20 \%$ dari BB tikus dan air $45 \mathrm{ml} /$ hari. Tikus ditempatkan pada 4 kandang persegi yang terbuat dari plastik dan kawat. Setiap kandang dipartisi menjadi 9 bagian untuk diisi masing-masing 1 ekor tikus.

\section{Inokulasi Streptococcus mutans}

Streptococcus mutans disiapkan dengan Colony Forming Unit (CFU) $10^{8} \mathrm{sel} / \mathrm{mL}$. Setelah tahap aklimatisasi, S. mutans diberikan secara oral pada mulut tikus sebanyak $0,2 \mathrm{ml}$ dengan menggunakan pipet selama tiga hari. Tikus langsung diberi perlakuan setelah inokulasi $S$. mutans berupa makanan dalam bentuk pelet dengan campuran sukrosa dan minuman ekstrak gambir. Ekstrak gambir diberikan dalam bentuk minuman yang dimasukkan pada botol minuman tikus. Proses perlakuan ini berlangsung selama 60 hari.

Setelah 60 hari, tikus dieutanasia dengan cara dimasukkan pada kotak kedap udara dan diberi kloroform selama 5 menit. Setelah itu, kedua rahang tikus diambil dengan menggunakan scalpel dan blade. Rahang tersebut dibersihkan dengan larutan amonium hidroksida $1-2 \%$ selama kurang lebih 30 menit. Pengawetan dilakukan dengan merendam rahang dalam formalin untuk mencegah pembusukan selama 24 jam.

\section{Penilaian Karies pada Tikus}

Penilaian karies pada gigi molar tikus putih galur Wistar menggunakan metode Keyes. Metode Keyes digunakan karena masih efektif untuk mengevaluasi karies pada hewan percobaan. Evaluasi dilakukan dengan cara melihat lesi karies berdasarkan kedalamannya dan dengan bantuan USB Digital Microscope (GT600, Firefly, USA) pada pembesaran 300-350x dari permukaan halus (bukal dan lingual atau palatal) dan permukaan oklusal (pit dan fisur). ${ }^{14}$ Sebelum dilakukan penilaian, dilakukan staining terlebih dahulu. Tahap staining dilakukan dengan merendam rahang menggunakan larutan $1 \%$ methylene blue selama kurang lebih 4 jam, kemudian rahang dibersihkan dan dikeringkan. Setelah itu dilakukan sectioning rahang tikus menggunakan carborundum disc yang dipasang pada straight handpiece. Langkah pertama dalam menilai lesi karies adalah dengan mengobservasi permukaan halus, yakni permukaan bukal dan lingual atau palatal, dilanjutkan dengan observasi pada permukaan oklusal gigi tikus secara visual. Observasi dilakukan dengan bantuan USB Digital Microscope. Karies yang terbentuk akan memperlihatkan adanya stain atau bercak yang berwarna biru baik pada permukaan halus, maupun permukaan oklusal gigi. Langkah berikutnya adalah dengan melihat kedalaman karies. Keyes 
Majalah Kedokteran Gigi Indonesia. Agustus 2017; 3(2): 83 - 92 ISSN 2460-0164 (print)

ISSN 2442-2576 (online)

mengklasifikasikan kedalaman karies menjadi 4 bagian, yaitu:

1. Email (E)

2. SlightDentinal (Ds)
: Lesi karies hanya mencapai daerah email.

: Lesi karies telah mencapai dentino email junction (DEJ) atau dentin terbatas.

3. Moderate Dentinal (Dm) : Lesi karies telah mencapai $1 / 4$ hingga $3 / 4$ kedalaman dentin.

4. Extensive Dentinal (Dx) : Lesi karies telah mencapai lebih dari $3 / 4$ kedalaman dentin.

Tikus Wistar memiliki 12 buah gigi molar dalam satu rahang. 3 gigi molar terdapat pada bagian belakang rahang bawah kanan, 3 molar pada rahang bawah kiri, 3 molar pada belakang rahang atas kanan dan 3 molar pada rahang atas kiri. Lebar pemukaan mesio-distal masing-masing gigi molar dibagi dalam beberapa unit, sesuai dengan lebar dari gigi tersebut. Molar satu dibagi dalam 4 unit, molar dua dalam 4 unit dan molar tiga dibagi dalam 6 unit (Gambar 1). Secara visual, karies dilihat dengan adanya stain yang berwarna biru, diamati mulai dari permukaan email hingga dentin dalam. Jumlah dari masing-masing karies pada setiap unit gigi molar tikus untuk satu gigi dicatat dan dibedakan berdasarkan tingkat kedalamannya. Jumlah karies tersebut kemudian digabungkan dengan jumlah gigi lainnya pada satu tikus. Metode double blind digunakan untuk menilai jumlah karies pada gigi tikus.

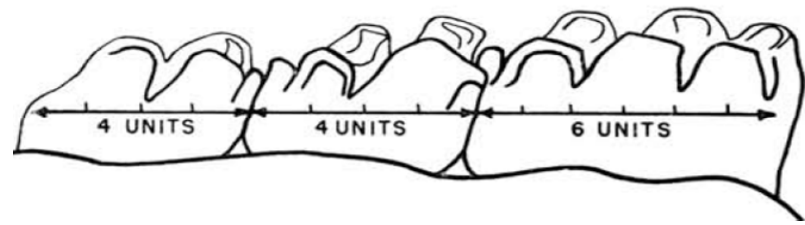

Gambar 1. Permukaan gigi tikus yang dibagi dalam beberapa unit berdasarkan lebar mesio-distalnya. Penilaian dilakukan dengan melihat karies yang terbentuk pada setiap unit, kemudian dijumlahkan.

\section{Analisis Data}

Data yang diperoleh dari hasil penelitian ini diuji normalitas dengan uji Shapiro-Wilk dan homogenitas dengan Levene's test. Oleh karena syarat normalitas data tidak terpenuhi, maka digunakan statistik non parametrik Kruskal Wallis.

\section{HASIL PENELITIAN}

Pada penelitian ini tikus diinduksi dengan $S$. mutans dan juga diberikan sukrosa. Pemberian S. mutans dan sukrosa diharapkan dapat membentuk karies pada gigi tikus. S. mutans diberikan secara oral ke dalam rongga mulut tikus selama tiga hari sedangkan sukrosa yang dicampur dalam makanan diberikan secara ad libitum setiap hari. Simon $\mathrm{L}$ (2007) menyebutkan bahwa S. mutans memiliki peranan penting sebagai penyebab terbentuknya karies gigi. ${ }^{15}$

Hasil penelitian menunjukkan tidak ditemukan adanya karies pada permukaan halus dari gigi tikus (Gambar 2) sehingga tidak dilakukan analisis data lebih lanjut. Karies terlihat hanya pada permukaan oklusal (pit dan fisur) dengan kedalaman email. (Gambar 3).

Pada Gambar 4 terlihat bahwa terdapat kecenderungan penurunan rata-rata jumlah karies pada permukaan oklusal gigi. Jumlah rata-rata karies gigi yang paling sedikit terbentuk ada pada kelompok dosis $24 \mathrm{mg} / 200 \mathrm{~g} \mathrm{BB}$.

Data hasil penelitian yang diuji dengan uji normalitas Shapiro Wilk menyatakan bahwa data tidak berdistribusi normal $(p<0,05)$ sehingga data diuji dengan menggunakan uji non parametrik Kruskal Wallis. Data hasil uji Kruskal Wallis dapat dilihat pada Tabel 1.

Tabel 1 menunjukkan bahwa data tersebut memiliki angka probabilitas sebesar 0,07 ( $p>0,05)$. Hal ini dapat dimaknai bahwa hipotesis yang menyatakan bahwa tidak ada perbedaan karies pada semua kelompok diterima, sehingga data di atas tidak perlu dilanjutkan ke uji Post Hoc MannWhitney. Analisis dari hasil uji tersebut menunjukkan bahwa ekstrak gambir tidak signifikan memiliki efek antikaries pada gigi tikus Wistar. 

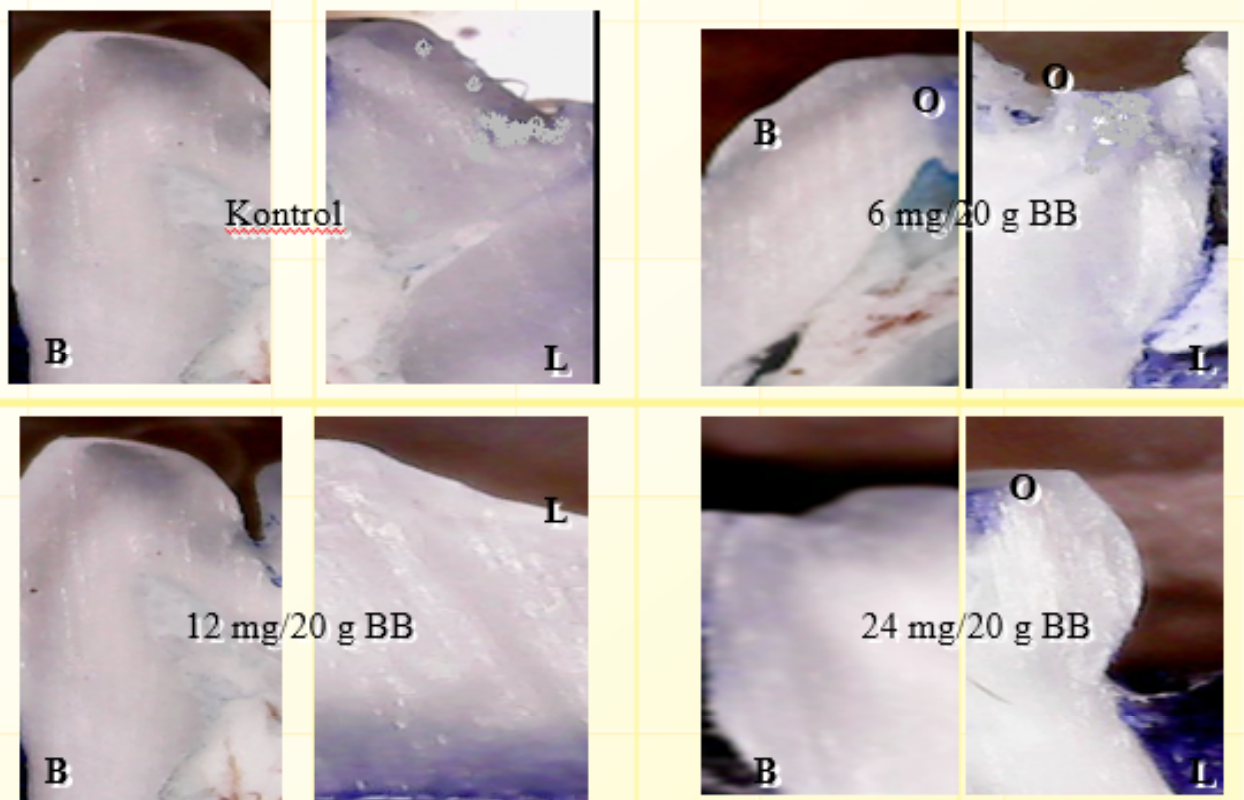

Gambar 2. Permukaan halus gigi tikus yang sudah direndam dengan larutan $1 \%$ methylene blue, dengan pembesaran $300 \times$ dilihat secara visual tidak terlihat adanya karies. ( $B=$ bukal; $\mathrm{L}=$ lingual; $\mathrm{O}=$ oklusal)
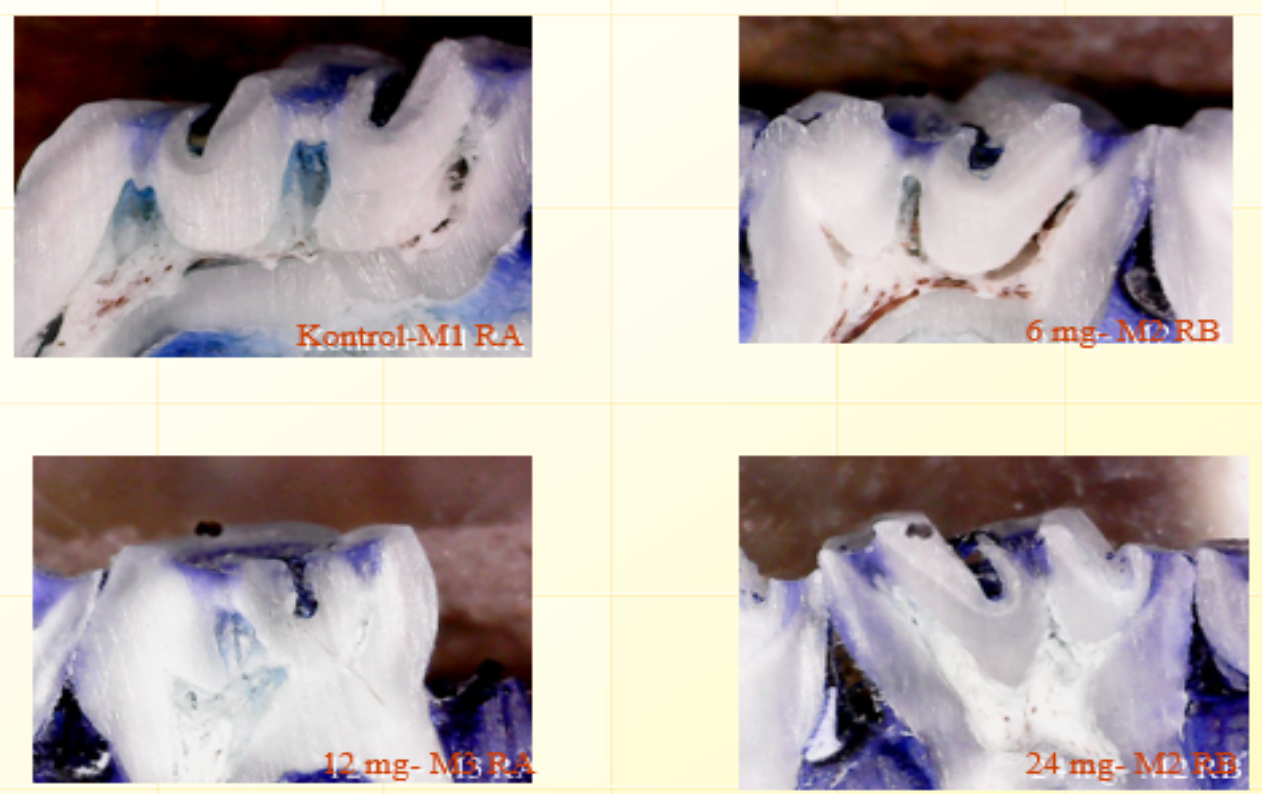

Gambar 3. Permukaan oklusal gigi tikus yang sudah direndam dengan larutan $1 \%$ methylene blue, terlihat karies dengan kedalaman email secara visual dengan menggunakan USB Digital Microscope 


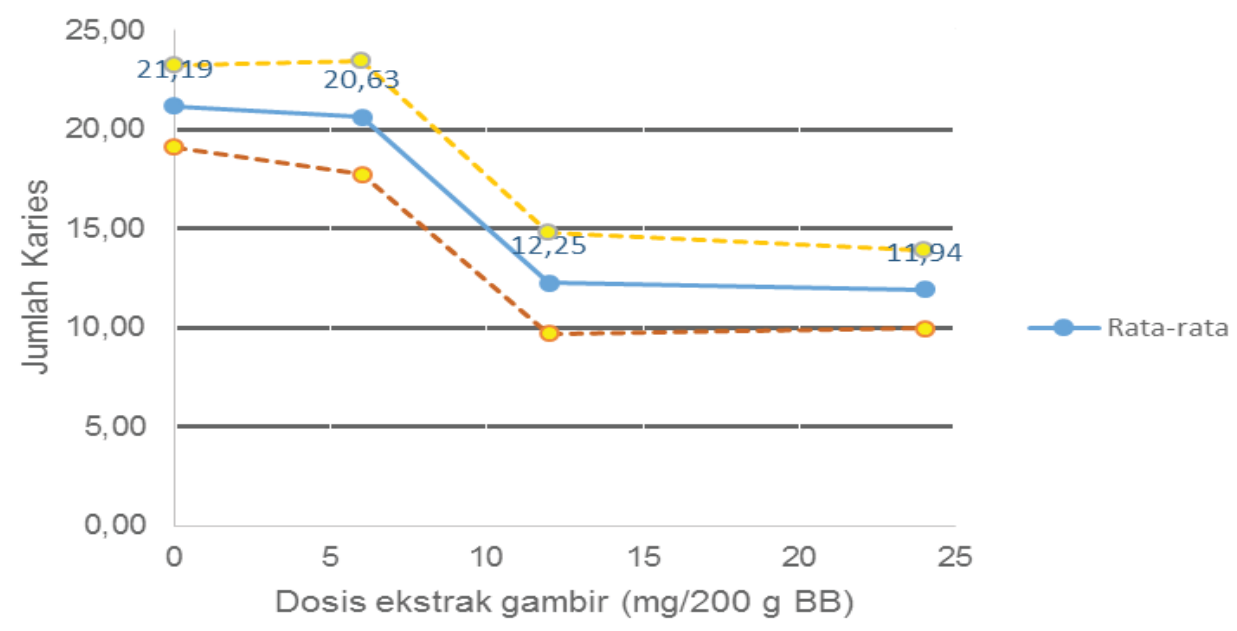

Gambar 4. Grafik rata-rata jumlah karies permukaan oklusal gigi tikus

Tabel 1. Uji Kruskal Walis efek anti karies ekstrak gambir pada gigi tikus

\begin{tabular}{|c|c|c|c|c|c|}
\hline & ompok & $\mathbf{N}$ & Mean \pm SD & Df & Sig \\
\hline \multirow{4}{*}{ Skor karies } & Plasebo & 8 & $21,19 \pm 2,09$ & \multirow{4}{*}{3} & \multirow{4}{*}{0,07} \\
\hline & $6 \mathrm{mg} / 200 \mathrm{~g} \mathrm{BB}$ & 8 & $20,63 \pm 2,87$ & & \\
\hline & 12 mg200 g BB & 8 & $12,25 \pm 2,54$ & & \\
\hline & $24 \mathrm{mg} / 200 \mathrm{~g} \mathrm{BB}$ & 8 & $11,94 \pm 1,99$ & & \\
\hline
\end{tabular}

\section{PEMBAHASAN}

Berdasarkan hasil dari penelitian ini, terlihat bahwa karies hanya tampak pada permukaan oklusal (pit dan fisur), sedangkan karies bagian permukaan halus bernilai 0 . Hal ini selaras dengan laporan Machale dkk (2013) yang menyebutkan bahwa prevalensi karies pada permukaan halus adalah $15 \%$, sedangkan pada permukaan oklusal lebih tinggi, yakni $38 \%$. Permukaan halus gigi beresiko lebih rendah terhadap karies dibandingkan permukaan oklusal, sehingga hanya karies bagian oklusal yang tampak. ${ }^{16} \mathrm{Hal}$ tersebut disebabkan karena permukaan halus lebih mudah diakses oleh saliva sehingga peran self cleansing nya berjalan. ${ }^{17}$ Saliva berperan sebagai buffer dan mengandung komponen antibodi rongga mulut sehingga bakteri patogen tidak dapat berkembang biak. ${ }^{18} \mathrm{Pit}$ dan fisur pada gigi posterior sangat rentan terhadap karies karena sisa-sisa makanan mudah menumpuk di daerah tersebut. ${ }^{19}$ Permukaan gigi yang kasar pada bagian oklusal juga dapat menyebabkan plak mudah melekat dan membantu perkembangan karies gigi. ${ }^{20}$
Penelitian ini juga memperlihatkan bahwa terdapat penurunan lesi karies pada permukaan oklusal, tetapi secara statistik tidak signifikan. Secara in vitro, gambir memiliki aktivitas antibakteri. Hal ini dibuktikan melalui penelitian yang dilakukan oleh Pambayun dkk (2007), yang menjelaskan bahwa senyawa katekin gambir yang bersifat polar mampu menembus lapisan peptidoglikan pada bakteri $S$. mutans yang juga bersifat polar. ${ }^{5}$ Katekin akan berikatan dengan salah satu molekul protein pada dinding sel sehingga fungsi protein terganggu dan dinding sel hancur. Kerusakan tersebut menyebabkan proses metabolisme sel terganggu hingga mengakibatkan kematian sel. ${ }^{21}$ Koech dkk (2013) mengatakan bahwa katekin efektif dalam menghambat pertumbuhan bakteri Gram positif, karena katekin dapat berikatan kuat dengan lipid bilayer pada bakteri Gram positif. ${ }^{22}$ Araghizadeh dkk (2013) menginformasikan bahwa katekin yang terdapat pada teh hijau sangat efektif dalam menghambat aktivitas bakteri kariogenik dan perio-patogen. ${ }^{23}$ 
Katekin juga mampu menghambat enzim glukosiltransferase agar tidak mensintesa sukrosa menjadi polisakarida ekstraseluler yang lengket. ${ }^{24}$ Koech menyebutkan bahwa senyawa polifenol polimer katekin bekerja dengan menginaktivasi enzim glukosiltransferase. ${ }^{22} \mathrm{Hal}$ tersebut menyebabkan $S$. mutans tidak lengket pada permukaan email gigi sehingga pembentukan plak dapat dicegah. Tsai dkk (2007) memaparkan bahwa senyawa polifenol katekin yang terdapat pada Rosmarinus officinalis dapat mencegah terbentuknya lesi karies dengan menekan enzim glukosiltransferase sehingga dapat mengeliminasi pembentukan plak gigi. ${ }^{25}$

Kandungan senyawa aktif lainnya dari gambir yang bersifat antibakteri adalah tannin. Kandungan tannin dalam gambir lebih sedikit dibanding senyawa katekin. ${ }^{26}$ Hasil penelitian yang dilakukan oleh Liantari (2014) menunjukkan bahwa tannin efektif menghambat aktivitas bakteri Streptococcus mutans. Tannin mampu menurunkan konsentrasi ion kalsium pada plasma, produksi enzim dan menghambat reaksi enzimatik oleh bakteri. ${ }^{27}$

Penelitian Dewi dkk (2016) mengenai efek antikaries ekstrak gambir (Uncaria gambir [Roxb.]) pada permukaan email gigi yang terpapar $S$. mutans, menyatakan bahwa gambir pada saliva buatan memiliki efek antikaries yang setara dengan cefadroxil $500 \mathrm{mg}$. Ekstrak gambir mampu menurunkan jumlah porositas permukaan email, mengurangi penurunan berat molekul kalsium, dan mengeliminasi koloni bakteri secara in vitro. ${ }^{28}$ Moezizadeh (2013) menyimpulkan bahwa efek antikaries katekin disebabkan karena kemampuan katekin dalam membunuh bakteri penyebab karies, membuat permukaan gigi menjadi halus atau licin sehingga bakteri membutuhkan waktu yang lebih lama untuk melekat pada gigi dan menurunkan kemampuan bakteri dalam memproduksi asam pada email. ${ }^{29}$

Penelitian ini memiliki hasil yang berbeda dengan penelitian yang dilakukan oleh Dewi dan Moezizadeh, dimana data yang didapat menunjukkan bahwa ekstrak gambir tidak signifikan memiliki efek antikaries, walaupun memiliki kecenderungan penurunan jumlah karies gigi tikus pada dosis $24 \mathrm{mg} / 200 \mathrm{gr} \mathrm{BB}$. Perbedaan hasil yang didapat tersebut disebabkan karena penelitian ini merupakan penelitian in vivo, sedangkan penelitian sebelumnya di atas merupakan penelitian in vitro. Pada penelitian in vitro, senyawa aktif suatu tanaman, seperti katekin yang terdapat pada ekstrak gambir, langsung berkontak dengan sel spesimen yang diujikan. Hal ini menyebabkan efektivitas dari senyawa aktif tersebut tetap stabil dalam dosis atau konsentrasi yang sama yang langsung bekerja pada sel target. Pada penelitian ini, ekstrak gambir masuk melalui sistem pencernaan tikus, sehingga dosis atau konsentrasi dari senyawa aktif tersebut dapat dipengaruhi oleh farmakokinetik dan farmakodinamik di dalam tubuh tikus. Senyawa tersebut akan mengalami suatu proses absorpsi, distribusi, metabolisme (biotransformasi) dan eliminasi untuk sampai di tempat tujuan dan memberikan efek. Selama perjalanan tersebut, dosis atau konsentrasi suatu senyawa aktif cenderung mengalami penurunan. $\mathrm{Di}$ samping itu, mekanisme kerja obat juga dipengaruhi oleh reaksi biokimia obat terhadap sel-sel yang ada di dalam tubuh, yang dapat memberikan efek yang berbeda-beda pada tiap individu. Hal ini mempengaruhi efektivitas senyawa aktif tersebut pada sel target. Faktor lain yang mempengaruhi diantaranya faktor fisiologis individual, seperti idiosinkrasi, yang mampu memberikan efek yang tidak dapat diprediksi.

Faktor lain yang mempengaruhi hasil penelitian adalah dosis dan waktu penelitian. Baskar (2014) melaporkan bahwa teh hijau yang mengandung zat aktif katekin memiliki efek yang dapat menghambat terbentuknya karies baik secara in vitro maupun in vivo pada tikus. Data tersebut dirangkum dari beberapa hasil penelitian terdahulu. Dosis terendah ekstrak teh hijau yang digunakan pada penelitian in vivo tersebut untuk memberikan efek adalah $60 \mathrm{mg} / 200 \mathrm{gr}$ BB tikus dan waktu penelitian yang yang dilakukan lebih lama, yakni 120 hari, ${ }^{30}$ sedangkan pada penelitian ini dosis ekstrak gambir yang digunakan jauh lebih kecil, yakni 6-24 mg/200 gr BB tikus dengan waktu yang lebih singkat, yakni 60 hari. Perbedaan rentang dosis tersebut diduga menyebabkan ekstrak gambir secara signifikan tidak memiliki efek antikaries pada gigi tikus, walaupun 
Pambayun dkk (2007) mengatakan bahwa senyawa polifenol katekin pada ekstrak gambir lebih tinggi dibandingkan dengan pada teh hijau. ${ }^{5}$ Waktu penelitian yang lebih singkat memungkinkan karies yang terbentuk belum begitu banyak, sehingga efek ekstrak gambir terhadap terjadinya karies belum dapat dilihat lebih jauh. Untuk itu dibutuhkan penelitian lebih lanjut mengenai dosis minimal ekstrak gambir yang efektif digunakan dan waktu yang lebih lama untuk memberikan dan memperlihatkan efek antikariogenik gambir secara in vivo.

Penelitian yang dilakukan oleh Dwi dkk (2016) menunjukkan bahwa ekstrak gambir dengan dosis 6-24 mg/200 gr BB, secara signifikan mampu menurunkan jumlah koloni bakteri pada saliva tikus, dimana efek antibakteri ekstrak gambir dengan dosis $24 \mathrm{mg} / 200 \mathrm{gr}$ BB setara dengan cefadroksil $500 \mathrm{mg}$ yang diberikan selama 7 hari berturut-turut. ${ }^{31}$ Akan tetapi berdasarkan penelitian yang telah dilakukan ini, jumlah koloni bakteri yang masih tersisa pada di rongga mulut tikus masih memungkinkan untuk menyebabkan terjadinya karies. Di samping itu, pada penelitian ini tikus diinduksi dengan bakteri $S$. mutans, sehingga jumlah bakteri kariogenik pada saliva tikus menjadi lebih banyak.

Hasil penelitian Dewi dkk (2016) menyebutkan bahwa ekstrak gambir mampu mencegah terjadinya karies gigi manusia. Hal ini terlihat dari berkurangnya porositas pada topografi permukaan email dengan alat ukur SEM (Scanning Electron Microscope) yang memiliki perbesaran $1000-8000$ kali. ${ }^{28}$ Alat ukur yang digunakan dalam penelitian ini adalah USB digital microscope, dengan perbesaran 50 - 500x. Gambar yang didapatkan pada objek untuk melihat karies sudah tampak jelas dan tidak kabur. Al-Hana dkk (2013) menggunakan USB digital microscope untuk melihat ada atau tidaknya fraktur pada dentin akar gigi yang diberikan bahan reinforced dan hasil yang didapatkan sudah cukup baik untuk diukur dan dianalisis. ${ }^{32}$ Penggunaan USB digital microscope pada penelitian ini sebenarnya sudah cukup untuk mendeteksi karies. Penampakan pada USB digital microscope pun juga sudah cukup jelas untuk melihat adanya kavitas, namun akurasi objek penelitian masih jauh lebih baik jika menggunakan SEM. Hal ini disebabkan karena SEM memiliki kemampuan untuk memperbesar objek sampai dengan $8000 x$ dan memiliki kualitas yang baik dalam mempertajam objek pencitraan. Dengan demikian diharapkan dengan menggunakan SEM, evaluasi karies pada permukaan halus dan oklusal gigi tikus memberikan hasil yang lebih akurat. Untuk itu dapat disarankan untuk pengamatan selanjutnya dapat dilakukan dengan menggunakan SEM.

\section{KESIMPULAN}

Berdasarkan dari penelitian yang telah dilakukan, maka dapat disimpulkan bahwa ekstrak gambir dengan dosis $6 \mathrm{mg}, 12 \mathrm{mg}$ dan $24 \mathrm{mg}$ tidak memiliki efek antikaries pada gigi tikus jantan galur Wistar. Peningkatan dosis menunjukkan penurunan karies pada gigi tikus jantan galur Wistar (dose-dependent effect).

\section{DAFTAR PUSTAKA}

1. Pintauli $\mathrm{S}$, Hamada T. Menuju gigi dan mulut sehat: penanggulangan dan pemeliharaan. $1^{\text {st }}$ ed. Medan: USU Press; 2010. 7.

2. Badan Penelitian dan Pengembangan Kementrian Kesehatan. Riset Kesehatan Dasar 2013. Jakarta: Depkes RI 2013; 2013. $114-118$.

3. Kidd EAM, Joyston-Bechal S. Dasar - dasar karies: penyakit dan penanggulangannya. Jakarta: EGC; 2012. 1 - 5, 8.

4. Fejerskov O, Kidd E. Dental caries: the disease and its clinical management. $2^{\text {nd }} e d$. UK: Blackwell Publishing Ltd; 2008. 166.

5. Pambayun R, Gardjito M, Sudarmadji $S$, Rahayu K. Kandungan fenolik ekstrak daun gambir (Uncaria gambir Roxb) dan aktivitas antibakterinya. Agritech. 2007; 27(2): 89 - 94.

6. Magdalena NV, Kusnadi J. Antibakteri dari ekstrak kasar daun gambir (Uncaria gambir var cubadak) metode microwave-assisted extraction terhadap bakteri patogen. Jurnal Pangan dan Agroindustri. 2015; 3(1): $124-$ 135. 
7. Liang $\mathrm{C}$, Zhang $\mathrm{Y}$, Jia $\mathrm{Y}$, Wang $\mathrm{W}$, Li $\mathrm{Y}$, Lu S, Jin JM, Tang SY. Engineering a carbohydrate-processing transglycosidase into glucosyltransferase for natural product glycodiversification [Internet]. Science Reports 6; 2016 [cited 2017 January 19.] Available from http://www.nature.com/articles/srep21051.

8. Pambayun R, Gardjito $M$, Sudarmadji $S$, Rahayu K. Sensitivitas bakteri gram positif terhadap katekin yang diekstraksi dari gambir (Uncaria gambir). Agritech. 2008; 28(4): 174 179.

9. Amos. Gambir sebagai antibakteri dalam formulasi obat kumur. Jurnal Sains dan Teknologi Indonesia. 2009; 11(3): 188 - 192.

10. Lucida H, Rustini, Saufitri D, Dachriyanus. Formulation of anti-plaque tooth paste from standardized gambir extractand its antimicrobial activity. Jurnal Farmasi Indonesia. 2010; 5(2): 70 - 77.

11. Ridwan E. Etika pemanfaatan hewan percobaan dalam penelitian kesehatan. J Indon Med Assoc. 2013; 63(3): 112 - 116.

12. Hasti S, Muchtar H, Bakhtia A. Uji aktivitas hepatoproteksi dan toksisitas akut dari ekstrak gambir terstandarisasi. Jurnal Penelitian Farmasi Indonesia. 2012; 1(1): 34 - 38.

13. Irdalisa, Safrida, Khairil, Abdullah, Sabri M. Profil kadar glukosa darah pada tikus setelah penyuntikan aloksan sebagai hewan model hiperglikemik. Jurnal EduBio Tropika. 2015; 3(1): $25-28$.

14. Guggenheim B, Hefti A, Burschard JJ. The effect of cyclosporin A on dental caries in rats monoassociated with Actimycess viscosus NY1. In McGhee JR, editor. Secretory Immunity and Infection. Proceeding of the International Symposium on the Secretory Immune System and Caries Immunity; 2012; New York. New York: Springer Sci and Bussiner media; 2012. $294-301$.

15. Simon L. The role of Streptococcus mutans and oral ecology in the formation of dental caries. JYI. 2007; 56: $11-20$.
16. Machale PS, Hedge-Shetiya S, Agarwal D. The incipient caries. J Contemp Dent. 2013: 3(1): $20-24$.

17. Veiga N, Aires D, Douglas F, Pereira M, Vaz A, Rama L, Silva M, Miranda V, Pereira F, Vidal B, Plaza J, Bexiga F. Dental caries: a review. J Dent Oral Health. 2013; 2(5): $43-45$.

18. Shetty C, Hedge MN, Devadiga D. Correlation between dental caries with salivary flow, $\mathrm{pH}$ and buffering capacity in adult South Indian population. Int. J. Res. Ayurveda Pharm. 2013; 4(2): $219-223$.

19. Fatmawati DWA. Hubungan biofilm Streptococcus mutans terhadap resiko terjadinya karies gigi. Stomatognatic. J.K.G Unej. 2011; 8(3): 127 - 130.

20. Rahmayanti S, Purnakarya I. Peran makanan terhadap kejadian karies gigi. Jurnal Kesehatan Masyarakat. 2013; 7(2): 89 - 93.

21. Taylor PW, Hamilton-Miller JMT, Stapleton PD. Antimicrobial properties of green tea catechins. Food Sci. Technol. Bull. 2005; 2: 71 $-81$.

22. Koech KR, Wachira FN, Ngure RM, Wanyoko JK, Bii CC, Karori SM. Antimicrobial, synergistic and antioxidant activities of tea polyphenols. Formatex 2013; 4: 971 - 981.

23. Araghizadeh A, Kohanteb J, Fani MM. Inhibitory activity of green tea (Camellia sinesis) extract on some clinically isolated cariogenic and periodontophatic bacteria. Med. Princ. Pract. 2013; 22: 368 - 372.

24. Reygaert WC. The antimicrobial possibilities of green tea. Front Microbiol. 2014; 5: 434 444.

25. Tsai PJ, Tsai TH, Ho SC. In vitro inhibitory effects of rosemary extract on growth and glucosyltransferase activity of Streptococcus sorbinus. Food Chem. 2007; 105: 311 - 316.

26. Kassim MJ, Hussin HM, Achmad A, Dahon $\mathrm{NH}$, Suan TK, Hamdan HS. Determination of total phenol, condensed tannin, flavonoid contents and antioxidant activity of Uncaria 
gambir extracts. Majalah Farmasi Indonesia 2011; 22(1): 50 - 59.

27. Liantari DS. Effect of Wuluh starfruit leaf extract for Streptococcus mutans growth. J Majority. 2014; 3(7): 27 - 33.

28. Dewi SRP, Kamaluddin MT, Theodorus, Pambayun R. Anticariogenic effect of gambir (Uncaria gambir [Roxb.] extract on enamel tooth surface exposed by Streptococcus mutans. Int J Health Sci Res. 2016; 6(8): 171 -179 .

29. Moezazideh M. Anticariogenic effect of tea: a review literature. JDOH. 2013; 5(9): 89 - 91.
30. Baskar S. Role of green tea in dental problems. IJCRCPS. 2014; 4(1): 73 - 77.

31. Dwi RS, Ardita I, Dewi SRP. Antibacterial effect of gambir extract (Uncaria gambir [Roxb.]) to bacterial colonies in male rat Wistar strain. Proceedings of FDI-IDA Joint Meeting: 2016 11-12 Nov; Bandung, Indonesia.

32. Al-Hana DAA, El-Messairy AA, Shohayb FH, Alhadainy HA. Micro-shear bond strength of different composite and glass-ionomers used to reinforced root dentin. Tanta Dental Journal. 2013; 10: 58 - 66 . 